〔農化 第 39 巻，第 9 号, p. $342 \sim 346,1965$ ]

グルタミン酸生産菌群の分類学的研究 (第 3 報)

DNA の塩基組成

高山健一郎, 阿部重雄, 木下祝郎（協和酬醉工業株式会社東京研究所）

昭和 40 年 5 月 10 日受理

\title{
Taxonomical Studies on Glutamic Acid Producing Bacteria
}

Part III. on the Base Composition of DNA

By Ken-ichiro TaKayama, Shigeo ABE and Shukuo KINOSHITA

Tokyo Research Laboratory, Kyowa Hakko Kogyo Co., Ltd.

The base compositions of DNA from representative strains belonging to twelve types of glutamic acid producing strains were measured.

The twelve types were, further, grouped into three groups according to the guaninecytosine content (G-C).

The group of 53\% G-C was consisted of type 1 to type 10 . The strains of this group showed higher activities of glutamic acid production than the other and rapidly produced acid from glucose. The most of glutamic acid producing microorgaminisms belong to this group.

The group of $53 \%$ G-C was consisted of type 11 which produced neither urease nor nitrites from nitrates.

The group of $65 \%$ G-C was consisted of type 12 which slowly and weakly produced acid from glucose and did not produce urease.

Thermal denaturation temperature (Tm) of M. glutamicus KY 9003 and KY 9002 which belonged to the group of $56 \% \mathrm{G}-\mathrm{C}$, were measured. The $\mathrm{Tm}$ of the former strain was $92.3^{\circ} \mathrm{C}$ (corresponds to $56 \% \mathrm{G}-\mathrm{C}$ ) and the $\mathrm{Tm}$ of latter was about $89^{\circ} \mathrm{C}$ (corresponds' to 48 $\% \mathrm{G}-\mathrm{C})$.

(Received May 10, 1965)

緒言

生物の種特異性が DNA の塩基組成あるいはその配列 の反映であるということは近年明らかにされてきた事実 である. バクテリアについてあLee ${ }^{(1)}$ 以来多くのデータ 茷報告され(2 7)，分類との関連性が諭議されてきている.

著者らは前報 ${ }^{(8)}$ に打いてグルダミン酸生産菌 207 株を 12 type に分類したが，その類緑性を明らかにする一助 として，それらの代表菌株について DNA を分離・調製 し程基組成を求めたので報告する。

\section{実 験 方 法}

（1）供試菌株：グルタミン酸生産菌各 type の代 表的な菌株 1〜数株を選び実験に使用した。なお対照実 蹒として E. coli K-12 を用いた。

（2）菌体： DNA 調製沉用いた菌体は次のように こてて得た.グルコース・ブイヨン 20 時間振燳培盖菌体
を種培㨍とし，500 $\mathrm{ml}$ グルコース・ブイヨン/21 ヒダ付 三角フラスコに $10 \%$ 宛接種，6 時間振䔽培養を行ない 遠心分離により集菌して陚料とした。

（3）DNA 調製法：DNA の調製は Marmur 法 ${ }^{(9)}$ 及び斎藤らの方法(10１1) を参考にし若干の改良を加えて 行なった. 調製法の概略を Fig. 1 に示与.

試薬

食塩-EDTA : $0.15 \mathrm{M} \mathrm{NaCl}+0.1 \mathrm{M}$ EDTA.

ラウリル硫酸ソーダ (SLS と略す).

フェノールー綬衝夜：フェノール：トリス-SLS 緩衝液 $=4: 1$.

トリス-SLS 㣪衝液：0.1 M-トリス緩衝液，1\% SLS, $0.1 \% \mathrm{NaCl}(\mathrm{pH} 9)$.

食塩ークエン酸ソーダ：0.15 M NaCl+0.015M クェン 酸ソーダ ( $\mathrm{pH} 7)$. 


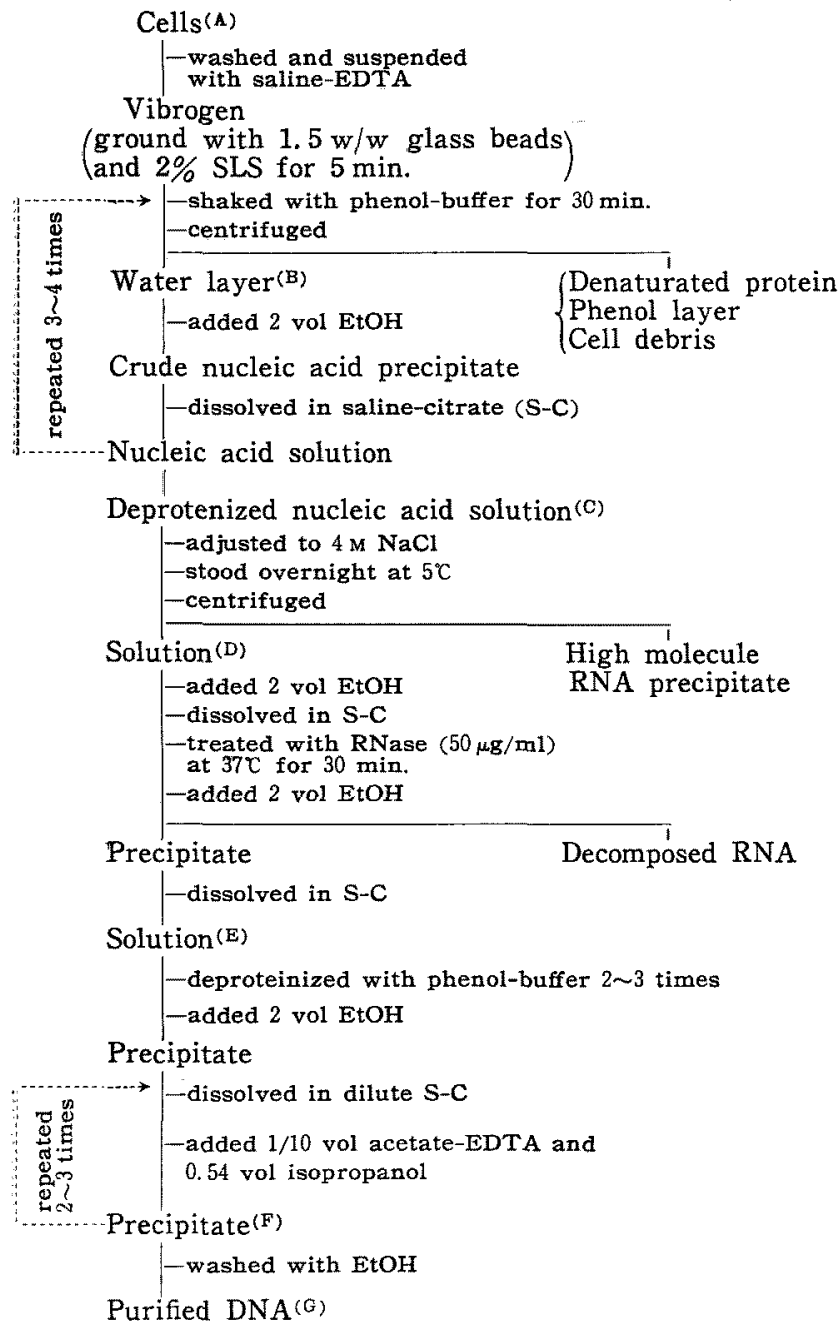

Fig. 1. Preparation Procedures for DNA (A) $\sim(G)$ : refer to Table II.

希食塩-クエン酸ソーダ: $0.015 \mathrm{M} \mathrm{NaCl}+0.0015 \mathrm{M}$ クェン酸ソーダ.

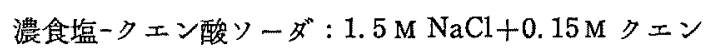

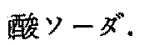

酢酸-EDTA : $3 \mathrm{M}$ 酷酸 ソーダ+0.001 M EDTA（pH 7).

リボヌクレアーゼ：第一化学薬品工業株式会社淛.

（4）定量法：DNA 各塩基の定量は Bendichの Methods in Enzymology 記載の方法 ${ }^{(12)}$ 亿準した。すな 方古 $70 \%$ 過塩素酸により $100^{\circ} ， 1$ 時間加水分解しイ》 プロパノール：塩酸：水=65:17:18 の溶媒により展 開分離し, $0.1 \mathrm{~N}$ 塩酸, $30^{\circ}, 1$ 時間振踾抽出, 遠心分離 上清測定し各吸収係数がら計算により各塩基量を求め
た。な和沪維は東洋沪紙 No. 51A を使用した。 融解温度 $(\mathrm{Tm})$ の測定は Marmur の方法(13) に従った。

細胞むるいは粗抽出物は Schmidt-Thannhauser 法(14)及び Schneider 法(15)により分画 分析した. DNA，RNA 及び蛋白質の定量はジ

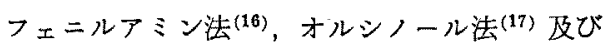
銅一フォリン法(18)によった。

\section{実験}

\section{（1）DNA の調製について}

DNA の調製は要するに菌体からの抽出と蛋 白筫及び RNA の除去にある. M. glutamicus の細胞壁が破壊され難い事実㭠に宇田川ら (19) が認めて扣り，また著者らも経験するとこらで 更，宇田川らはリゾチーム，トリプシン，超 音波の3 処理により溶菌させ DNAを得ている が，その取率はよくない。

溶菌法として種々の方法が用いられているが， $\operatorname{Marmur}^{(9)}$ ，斎藤(11)によるとSLS 及びりゾチ 一ム処理が分子量並びに形質転換能の点から最 良とされている。

そこで SLS 及びリゾチーム処理を中心とし てグルタミン酸生産菌の溶菌を試み，此濁の減 少, DNA 抽出率 (フェノール1回処理後)の 点から検討した結果が Table I である.SSS

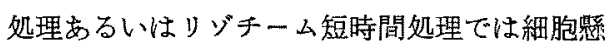
濁液の粘程化は起らす DNA るほとえど抽出さ れない、リゾチーム2 時間処理, 凍結融解後 SLS 処理を行なうとかなり溶菌が認められ,

Table I. Recovery of DNA by Various Methods

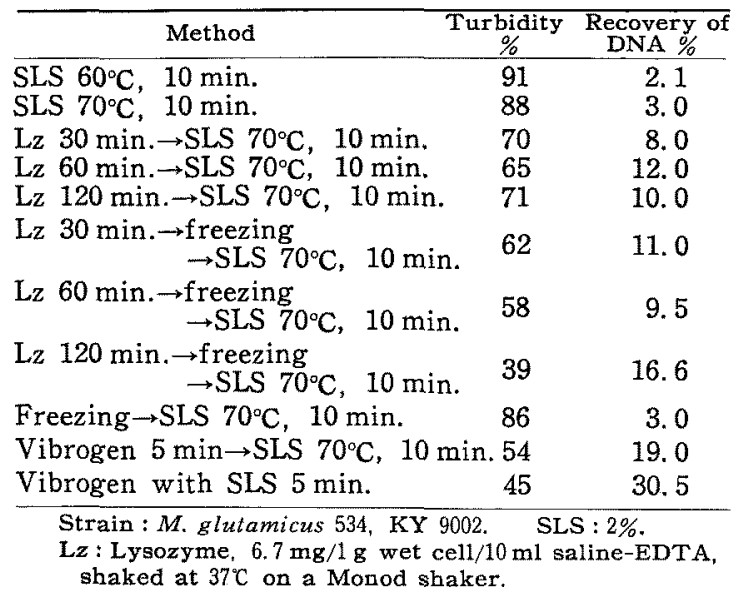


Table II. Purification of DNA

\begin{tabular}{|c|c|c|c|c|c|}
\hline & Sample & $\begin{array}{c}\text { DNA } \\
\text { mg }\end{array}$ & $\begin{array}{c}\text { RNA } \\
\mathrm{mg}\end{array}$ & $\begin{array}{l}\text { RNA } \\
\text { DNA }\end{array}$ & $\begin{array}{c}\text { Recovery } \\
\text { of DNA } \\
\%\end{array}$ \\
\hline (A) & Whole cell (wet packed : $10 \mathrm{~g}$ ) & 95.0 & 600 & 6.3 & 100 \\
\hline (B) & 1 st phenol-buffer treatment & 23.0 & 130 & 5.7 & 24.2 \\
\hline (C) & Deproteinization & 19.2 & 99 & 5.2 & 20.2 \\
\hline (D) & $4 \mathrm{M}-\mathrm{NaCl}$ treatment & 18.5 & 19.5 & 1.05 & 19.5 \\
\hline (E) & RNase treatment & 15.3 & 3.6 & 0.24 & 16. 1 \\
\hline (F) & 1 st isopropanol precipitate & 13. 0 & 1.6 & 0.12 & 13.7 \\
\hline (G) & $3 \mathrm{rd}$ isopropanol precipitate & 11.2 & 0.4 & 0.04 & 11.8 \\
\hline
\end{tabular}

Strain : $M$. glutamicus 534 (KY 9002) (A) (G) : see Fig. 1

$0.3 \mathrm{mg}$ protein contained in the sample (G)

DNA も抽出されるが抽出率は Vibrogen (ドイッ Buhler 社製，ガラス玉と振璗磁码）に劣る，リゾチーム処理の 場合，振蕰条件がかなり影瑟しているような事実が認め られた。またヒューズ・ブレス（大岳裂作所製）を使用 したところ, Vibrogen 処理の境合と同程度の DNA 標 品が得られた。

Table II は DNA 精製過程における DNA 及び RNA の取率，含量比の一例を示したものである。菌体量は湿 量 $10 \mathrm{~g}$ (乾量 $3.3 \mathrm{~g}$ 火相当) である.蛋白質の除去に
はフェノールの他にクロロホルム、オクタ ノールなどが用いられて敊り，各々一長一 短が安るが，フェノールは他に較べて除蛋 由の操作回数が少ないことが大さな利点で ある. RNA の除去にはリボヌクレアーゼ 処理の他，高濃度食塩で高分子 RNA を沈 殿除去する方法(20)を併用して効果を得た。 その後イソプロパノール沈殿を数回繰り返 すことによりかなり純粋な DNA が得られ た。

（2）グルタミン酸生産菌各 type の DNA の塩基 組成

前報 ${ }^{(8)}$ に示したグルタミン酸生産菌各 type の代表菌、 株について DNA の塩基組成を求めた結果が Table III である。

Type 1〜10 の菌群はグルタミン酸生産能の高いグル ープであるが, これらの G-C 含量は 56〜57\% である. これに反して Type 11 すなわちウレアーゼ, 硝酸還元 ともに陰性の菌株は 2 株とす $53 \%$ でやや低い值を示し

Table III. Base Composition of DNA from Glutamic Acid Producing Strains.

\begin{tabular}{|c|c|c|c|c|c|c|c|}
\hline \multirow{2}{*}{ Type } & \multirow{2}{*}{ Strain } & \multicolumn{4}{|c|}{ mol. \% } & \multirow{2}{*}{$\frac{\text { Pur }}{\text { Pyr }}$} & \multirow{2}{*}{$\begin{array}{c}\text { G-C } \\
\%\end{array}$} \\
\hline & & $G$ & A & $\mathrm{C}$ & $\mathrm{T}$ & & \\
\hline 1 & $\left\{\begin{array}{lll}\text { KY } & 9002 \text { (M. 534, ATCC 13032) } \\
\text { KY } & 3805 \text { (Brevib. aminogenes No. 9) } \\
\text { KY } & 3460 \text { (Brevib. divaricatum NRRL 2311) } \\
\text { KY } & 10122 \text { (Brevib. flavum ATCC 14067) } \\
\text { KY } & 3509 \text { (Coryneb. lilium NRRL B-2243) } \\
\text { KY } & 9614 \text { (Brevib. saccharolyticum ATCC 14066) } \\
\text { KY } & 10125 \text { (Brib } \\
\text { KY } & 10124 \text { (Brevib. roseum ATCC 13825) } \\
\text { KY } & 10026 \text { (Brevib. lactofermentum ATCC 13869) } \\
\text { KY } 10123 \text { (B) }\end{array}\right.$ & $\begin{array}{l}28.2 \\
28.6 \\
28.4 \\
28.2 \\
28.6 \\
29.0 \\
28.5 \\
28.6 \\
29.1 \\
29.0\end{array}$ & $\begin{array}{l}21.5 \\
21.5 \\
21.0 \\
21.5 \\
21.9 \\
21.7 \\
21.5 \\
21.9 \\
21.5 \\
21.5\end{array}$ & $\begin{array}{l}28.6 \\
28.2 \\
28.6 \\
28.6 \\
28.2 \\
28.0 \\
28.0 \\
28.0 \\
27.8 \\
27.6\end{array}$ & $\begin{array}{l}21.7 \\
21.7 \\
22.0 \\
21.7 \\
21.3 \\
21.3 \\
21.0 \\
21.5 \\
21.6 \\
21.8\end{array}$ & $\begin{array}{l}0.99 \\
1.00 \\
0.98 \\
0.99 \\
1.02 \\
1.03 \\
1.00 \\
1.02 \\
1.02 \\
1.01\end{array}$ & $\begin{array}{l}56.8 \\
56.8 \\
57.0 \\
56.8 \\
56.8 \\
57.0 \\
56.5 \\
56.6 \\
56.9 \\
56.6\end{array}$ \\
\hline 2 & KY 9606 & 28.2 & 21.5 & 28.3 & 22.0 & 0.99 & 56.5 \\
\hline 3 & KY 9005 (M. 588) & 29.2 & 20.8 & 28.3 & 21.7 & 1.00 & 57.5 \\
\hline 4 & KY 9003 (M. 560, ATCC 13761) & 29.5 & 21.1 & 28.2 & 21.2 & 1.02 & 57.7 \\
\hline 5 & $\begin{cases}\text { KY } & 10021 \\
\text { KY } & 3807 \text { (Brevib. aminogenes No. 121) }\end{cases}$ & $\begin{array}{l}28.6 \\
29.2\end{array}$ & $\begin{array}{l}21.2 \\
21.3\end{array}$ & $\begin{array}{l}28.2 \\
28.5\end{array}$ & $\begin{array}{l}22.0 \\
21.0\end{array}$ & $\begin{array}{l}0.99 \\
1.02\end{array}$ & $\begin{array}{l}56.8 \\
57.7\end{array}$ \\
\hline 6 & $\left\{\begin{array}{l}\text { KY } 9026 \\
\text { KY } 3462 \text { (Brevib. ammoniagenes Aida) }\end{array}\right.$ & $\begin{array}{l}28.8 \\
28.7\end{array}$ & $\begin{array}{l}21.3 \\
22.8\end{array}$ & $\begin{array}{l}27.5 \\
26.9\end{array}$ & $\begin{array}{l}22.4 \\
21.6\end{array}$ & $\begin{array}{l}1.00 \\
1.06\end{array}$ & $\begin{array}{l}56.3 \\
55.6\end{array}$ \\
\hline 7 & KY 9610 & 28.4 & 22.0 & 27.8 & 21.8 & 1.01 & 56.2 \\
\hline 8 & KY 9594 & 29.7 & 21.4 & 27.0 & 21.9 & 1.04 & 56.7 \\
\hline 9 & $\begin{cases}\text { KY } & 9024 \\
\text { KY } & 3461 \text { (Brevib. divaricatum NRRL 2312) } \\
\text { KY } & 10126 \text { (Brevib. immariophilium ATCC 14068) } \\
\text { KY } & 10127 \text { (Coryneb. acetoacidophilum ATCC 13870) }\end{cases}$ & $\begin{array}{l}28.0 \\
27.7 \\
28.2 \\
28.8\end{array}$ & $\begin{array}{l}21.8 \\
21.9 \\
21.5 \\
20.3\end{array}$ & $\begin{array}{l}28.0 \\
27.8 \\
28.2 \\
28.5\end{array}$ & $\begin{array}{l}22.2 \\
22.6 \\
22.1 \\
22.5\end{array}$ & $\begin{array}{l}0.99 \\
0.98 \\
0.99 \\
0.97\end{array}$ & $\begin{array}{l}56.0 \\
55.6 \\
56.4 \\
57.3\end{array}$ \\
\hline 10 & KY 9602 & 28.4 & 21.1 & 28.6 & 21.9 & 0.98 & 57.0 \\
\hline 11 & 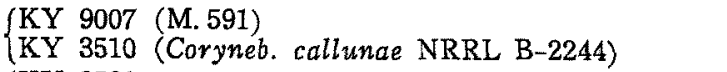 & $\begin{array}{l}26.5 \\
26.7\end{array}$ & $\begin{array}{l}23.4 \\
23.8\end{array}$ & $\begin{array}{l}27.1 \\
26.4\end{array}$ & $\begin{array}{l}23.1 \\
23.1\end{array}$ & $\begin{array}{l}1.00 \\
1.02\end{array}$ & $\begin{array}{l}53.6 \\
53.1\end{array}$ \\
\hline 12 & $\begin{cases}\mathrm{KY} & 9591 \\
\mathrm{KY} & 10101\end{cases}$ & $\begin{array}{l}33.6 \\
31.5\end{array}$ & $\begin{array}{l}17.6 \\
18.5\end{array}$ & $\begin{array}{l}32.0 \\
32.9\end{array}$ & $\begin{array}{l}16.8 \\
17.1\end{array}$ & $\begin{array}{l}1.03 \\
1.00\end{array}$ & $\begin{array}{l}65.6 \\
64.4\end{array}$ \\
\hline & E. coli $\mathrm{K}-12$ & 25.6 & 24.7 & 24.9 & 24.8 & 1.01 & 50.3 \\
\hline
\end{tabular}

G: Guanine, A : Adenine, C: Cytosine, T: Thymine, Pur: Purine, Pyr:Pyrimidine 
Table IV. G-C content of DNA by Tm and Chemical Analysis.

\begin{tabular}{|c|c|c|c|c|}
\hline \multirow{2}{*}{ Strain } & \multirow{2}{*}{$\underset{\text { Iment }}{\text { Experi- }}$} & \multicolumn{2}{|c|}{$T m$} & \multirow{2}{*}{$\begin{array}{l}\text { Chem. } \\
\text { Anal. } \\
\text { G-C } \%\end{array}$} \\
\hline & & $\overline{\operatorname{Tm}(C)}$ & $\mathrm{G}-\mathrm{C} \%$ & \\
\hline KY 9002 (Type 1) & $\begin{array}{l}1 \\
2 \\
3\end{array}$ & $\begin{array}{l}89.1 \\
87.9 \\
89.4\end{array}$ & $\begin{array}{l}48.3 \\
45.4 \\
49.0\end{array}$ & $\begin{array}{l}56.8 \\
56.3 \\
56.7\end{array}$ \\
\hline KY 9003 (Туре 4) & & 92.3 & 56.1 & 57.7 \\
\hline E. coli $\mathrm{K}-12$ & $\begin{array}{l}1 * \\
2^{* * *}\end{array}$ & $\begin{array}{l}91.0 \\
90.5\end{array}$ & $\begin{array}{l}52.9 \\
51.7\end{array}$ & $\begin{array}{l}51.0 \\
50.3\end{array}$ \\
\hline
\end{tabular}

* lysis with SLS, ** lysis with vibrogen

た。 また炭水化物から酸の生成が弱くウレアーゼ陰性の Type 12 は試験した 2 株とも 65\%でかなり高い値を示 した.

\section{(3) 融解温度 (Tm)}

DNA の G-C\%をTmから求める方法が Marmur ${ }^{(9,21)}$ により提晿され，2〜3 の研究者によりデータが報告さ れている(4,22-25)、著者らも若干の DNA 標品について Tm を測定したのでその結果の一部を Table IV に示 t.

Tm の值にかなりのふれが生じるため確定的な結論は いえないが，KY 9002 の場合 Tm から計算した $\mathrm{G}-\mathrm{C} \%$ は化学分析から求めた值に較へて低い值を示すことは明 らかである.これに反して KY 9003 の場合はほ添同じ 值を示した。一方 $E$. coliについて, SLS 処理及びVibrogen 処理の 2 方法によって DNA を調製し，Tm 法及 び化学分析汇よって G-C 含量を求めたが，両者とも同 様の結果が得られた．従って KY 9002 飞括忛る差違が DNA 調製法にのみ起因しているとは断定でさない，

Smith ${ }^{(22)}$ は軟体動物の DNA で Tm 密度勾配遠心 法, 楜原ら ${ }^{(24)}$ 怯枯草菌胞子 DNA て Tm と化学分析の 方法で測定した G-C 含量が異なることを報告している。 これらの事実から $\mathrm{Tm}$ の值は壏基組成以外何らかの 条件影響されていると考光られる。

グルタミン酸生産菌は塩基組成 (G-C\%)の点から 53 , 56 及び 65 の グループに分故られ. 各ダループの菌 学的性質の差遠を Table V K要約する.

G-C 比 $56 \%$ のグループはこれまでM. glutamicus として報告してきた M. 534 (ATCC 13032)，M. 560 (ATCC 13761) あるいは Brevib. aminogenes, B. divaricatum, B. flavum, B. lactofermentum, B. roseum, B. saccharolyticum, Coryneb. lilium などグルタミン 酸生産能の極めて高い菌株を含む.このグループに属す
Table V. Relation between G-C content and Physiological Characteristics of Glutamic Acid Producing Strains.

\begin{tabular}{|c|c|c|c|c|}
\hline G-C $\%$ & $\begin{array}{l}\text { Acid from } \\
\text { glucose }\end{array}$ & Urease & $\mathrm{NO}_{2}$ & Type \\
\hline $55.5 \sim 57.7$ & $\begin{array}{l}+ \\
+ \\
+\end{array}$ & $\begin{array}{l}+ \\
+ \\
-\end{array}$ & $\begin{array}{c}+,(+) \\
- \\
+\end{array}$ & $\begin{array}{c}1 \sim 8 \\
9 \\
10\end{array}$ \\
\hline $53.1 \sim 53.6$ & + & - & - & 11 \\
\hline $64.5 \sim 65.6$ & $(t)$ & - & + & 12 \\
\hline
\end{tabular}

$(+)$ : slowly and weakly positive

る Type 1〜10 はウレアーゼ，硝酸䢱元性，シュクロー ス, サリシン, マンニット，マルトースからの酸生産能 中若千を異にしているが，これらの違いたよって塩基組 成は異ならないまた Type 1 は最も多くの菌株を含ん でいるが、試験した 10 菌株は菌体色素（黄，淡黄，孚 白，淡桃），硝酸逞元性の強弱，メチルレッド試験の弱陰， 菌環あるいは菌膜を容易に形成するるのとしないるの， ビオチン以外にビダミン $\mathrm{B}_{1}$ を要求するすのなどの堂い があるが，これらの違いによっても塩基組成は異ならな W.

G-C 比 53\% のグループは Type 11 の KY 9007 及 び Coryneb. callunae の 2 菌株であり，前者が黄色，後 者が乳白色である以外は同一でウレアーゼ，硝酸還元性 とも陰性である。亦大耐菌株之もDNA 調製の際，沈 殿が繊維状になり難く精製が困難であった。

G-C 比 $65 \%$ のグループは Type 12 であり,グルニ 一スからの酸生成がやや劣りウレアーゼ陰悂である．寒 験に用いた 2 菌株は酸生成の点で若干異なるが， 2 株を もグルコース・ブイヨンと晾ける生育が不良で菌体収量 が悪かった。

このようと Type 11 及び Type 12 は塩基組成のみ ならず，DNA 調製過程に括ける様相も G-C 比 $56 \%$ の グループと異なっている，それ故 Table V に示した以 外の性質む異なっていることも考えられる。

われわれはこ礼までグルタミン酸生産菌を一括して Micrococcus glutamicus (Corynebacterium glutamicum(26-27)）と呼んできた：今回の実験によって Type 1 〜10のグループは塩基組成も同一であることが判り，多 くの菌学的諸特性む共通であるところから，同一 species むるいは亟めて近縁の speciesであることがあらためて 確認された. Type 11 及び Type 12 の菌株は DNAの 塩基組成が異なる。塩基組成の異なる菌株を同一種名で 呼ぶことは無理であるかも知れない。しかしながら，現 
在バクテリアの分類とDNA の塩基組成の関係に定かな 確説はない.

Bacillus subtilis( ${ }^{(6)}$, Bacillus megatherium(6), Bacillus cereus(4) などに出いては同一 species の中に塩基 組成の異なる菌株が含まれている，Escherichia，Salmonella, Shigellaは species (genus) を異にするが塩 基組成は同㥞であり ${ }^{(1-9)}$, 遗伝形質の伝達が可能であ $る^{(28)}$.また Bacillus subtilis と Bacillus megatherium の間 ${ }^{(6)}$ ，あるい性 Neisseri 属間(5) 飞执いては, 塩基組 成, species が異なるにもかかわらず遗伝形質の伝達の 可能な場合がある。

上記の例からもわかるように，塩基組成と分類との関 係には種々の矛盾が含まれて招り，今後の研究の進展が 待たれる.グルタミン酸生産菌群は Table V に示した

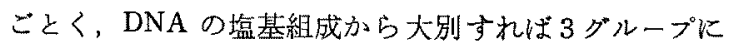
分別しうるが, 諸種の菌学的性質, グルタミン酸生産能 力の钼点から, Corynebacterium glutamicum (Micrococcus glutamicus) として総括したい.

\section{要約}

グルタミン酸生産菌株各 type の代表菌株について DNAをMarmur 及び斎藤らの方法に若干の改良を加 古て調製し，その塩基組成を求めた。

グルタミン酸生産菌は塩基組成の点から 3 グループに 分かれる、 G-C 比 56\%のグループは Type 1〜10で グルタミン酸生産能が特に高く、グルコースからの酸生 成が速やかな菌群であり，グルタミン酸生産菌株の大多 数を占好る，G-C 比 $53 \%$ のグループはウレアーゼ，硝 酸還元ともに陰性の Type 11，G-C 比 65\%のグループ はグルコースから酸生成能弱くウレアーゼ陰性の Type 12 が該当する。

融解温度 (Tm) を測定したところ， G-C 比 $56 \%$ の 菌株中 KY 9003 は $92.3^{\circ}$ (G-C 比 $56 \%$ に相当)，KY 9002 は恬ば $89^{\circ}$ (はは $48 \%$ に相当) と翼なる值を示し た.

終りに臨み，本報文に対し御校閲を賜った東大応微研 北原覚雄先生並びに御指導御鞭婞を睗った東大応微研斎 藤日向先生に厚く御礼申し上げます。また実験に御協力 いただいた阿保光子裹に深謝する。

本報告の要旨は昭和 39 年 7 月 19 日, 日本農芸化学会 大会で発表した.
(1) K. Y. Lee, R. Wahl, E. Barbu : Ann. Inst. Pasteur, 91, 212 (1956).

(2) A. N. Belozersky, A.S.Spirin : "The Nucleic Acids", Vol. 3, ed. by E. Chargaff and J.N. Davidson, Academic Press, New York, p. 147 (1960).

(3) N. Sueoka : J. Mol. Biol., 3, 31 (1960).

(4) W.C. McDonald et al., : J. Bact., 85, 1071 (1963).

(5) B. W. Caltin, L. S. Cuningham : J. Gen. Microbiol., 26, 303 (1961).

（6）斎藤日向：日生化総会講演 $(1963,10$, 東京).

（7）鈴木慈郎，北原覚雄 : 日潧化大会講演 (1963, 4 , 東京).

（8）高山徤一郎, 阿部重堆，木下祝郎： 本誌, 39, 335 (1965).

(9) J. Marmur : J. Mol. Biol., 3, 208 (1961).

(10) H. Saito, K. Miura : Biochim. Biophys. Acta, 72, 619 (1963).

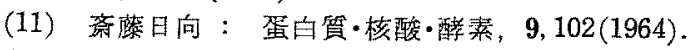

(12) A. Bendich : Methods in Enzymol., 3, 715 (1957).

(13) J. Marmur, P. Doty: J. Mol. Biol., 5, 109 (1962).

(14) C. Schmidt, S. J. Thannhauser : J. Biol. Chem., 161, 83 (1945).

(15) W. C. Schneider : ibid., 161, 293 (1945).

(16) Z. Dische: "The Nucleic Acids", Vol. 1, ed. by E. Chargaff and J., N. Davidson, Academic Press, New York p. 285 (1955).

(17) G. Ceriotti : J. Biol. Chem., 214,59(1955),

(18) O. H. Lowry et al. : ibid., 193, 265(1951).

（19）宇田川清, 阿部重雄, 木下祝郎：日䝮化大会 掣演 (1961，4, 福岡).

(20) 川出由已, 北村已も子：日化, 78, 1801(1957).

(21) J. Marmur, P. Doty : Nature, 183, 4673 (1959).

(22) M. Smith, D. B. Quayle : ibid., 200, 676 (1963).

（23）飯塚広，新井英夫，西村行正：日農化大会 䛾演 $(1964,7$, 札璂).

（24）榊原詳公, 斎藤日向, 池田厥之助：日農化大 会講演 (1964, 7, 札愰).

(25) G. F. Gause et al. : Nature, 203, 598(1964).

(26) 木下祝郎, 板垣史郎, 中山 清 : Amino Acids, 2, 42 (1960).

(27) S. Kinoshita : Recent Progress in Microbiol., 8, 334 (1962).

(28) S. E. Luria, J. W. Burrous : J. Bact., 74, 461 (1957). 